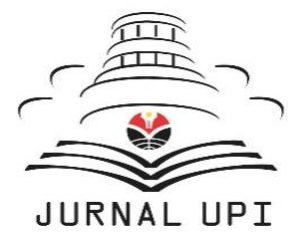

INDONESIAN JOURNAL OF APPLIED LINGUISTICS

Vol. 9 No. 3, January 2020, pp. 572-579

Available online at:

https://ejournal.upi.edu/index.php/IJAL/article/view/23207

doi: 10.17509/ijal.v 9i3.23207

\title{
Indonesia Islamic senior high school students' English learning conceptions and strategies
}

\author{
Euis Rina Mulyani*, Didi Suherdi, and Wachyu Sundayana \\ Department of English Education, Faculty of Language and Literature Education, Universitas Pendidikan Indonesia, \\ Jalan Dr. Setiabudhi No. 229 Bandung, West Java, Indonesia
}

\begin{abstract}
This study was inspired by previous studies of how students' learning influences their learning beliefs and, in turn, their strategies. Unfortunately, few studies concern learners' conceptions of learning, in particular in learning English, and paid less attention to the senior high school students level. With the intention to identify Islamic senior high school. Interviews and both close and open questionnaires were used to collect relevant data. To identify students' conception, Purdie and Hattie's COLI items were used; and Oxford's SILL to identify learning strategies. Data collected from the close questionnaire were analyzed by quantifying the frequency and the average of particular issues, which include the preference of students' learning conception and learning strategies. Meanwhile, data from interviews and open questionnaire were analyzed using Miles and Hubberman's (1994) framework of qualitative data analyses. Overall, data analyses results showed that, in terms of their conceptions, most students conceived learning as a duty - in order to able to make their parents happy, to serve the community with their knowledge, and most of all, as a way to show their devotion to Allah the all mighty. In addition, most students favored metacognitive learning strategies in learning English. This study came to the conclusion that although the tendency of students' conception of learning English was at the surface level of learning, most of the students used relatively complex and high-level strategies when it came to their English learning process as they used metacognitive strategies.
\end{abstract}

Keywords: Conceptions of learning English; Islamic senior high school; strategies to learn English

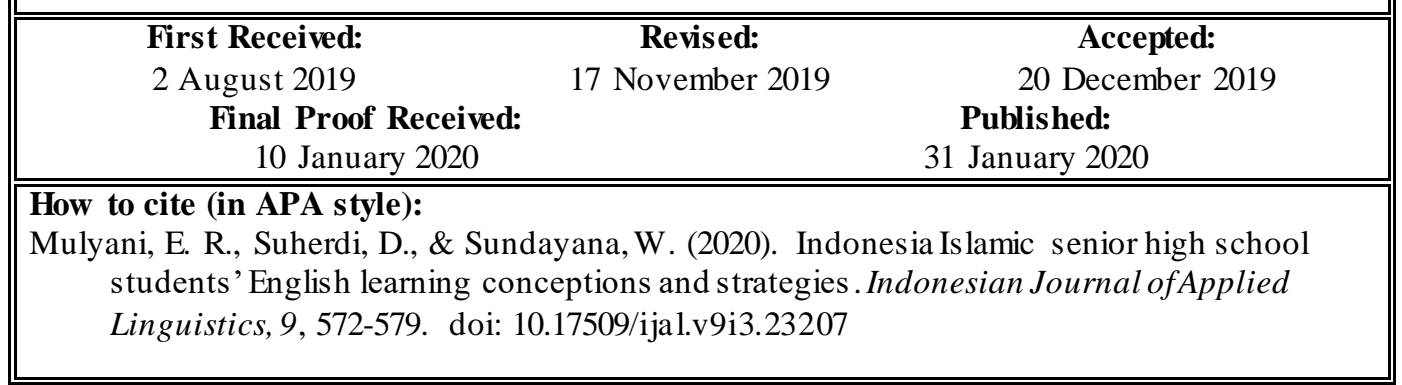

\section{INTRODUCTION}

Learning involves a series of interrelated learning aspects such as process, demands, orientations, advantages, and motivations (Klatter, Lodewijks, \& Aarnoutse). Its successfulness is influenced by many factors such as learning conceptions (Säljö, 1979), learning styles (Entwistle \& Peterson, 2004), learning strategies (Oxford \& Ehrman, 1995; Oxford, 1996), learning contexts (Malone \& Tranter, 2003; Saengboon, 2004), and learning engagement (Suherdi, 2018). Therefore, it requires learners to use all their cognitive, personal, social, and affective domains (Entwistle \& Peterson, 2004).
Among the learning factors, conceptions can be viewed at a higher order of students' learning factors since it can shape the belief of the learners about the learning (Benson \& Lor, 1999) which in turn may lead their ways of learning (Byrne \& Flood, 2004) including its strategies. Unfortunately, few studies concern learners' conceptions of learning, in particular in learning English. In addition, studies on learning conceptions mostly emphasized higher education students' level and paid less attention to the senior high school students' level. Moreover, to date, studies concerning students' learning conceptions, along with their learning strategies, haven't been found yet. To fill

\footnotetext{
* Corresponding Author

Email: euisrinamulyani@gmail.com
} 
the gap, this study is interested in investigating senior high school students' conceptions and strategies in learning English.

\section{Conceptions of learning}

Conceptions of learning are concerned with "what a learner thinks the objects and process of learning" (Benson and Lor, 1999) or "what learning means to the learner" (Marton, Dall'Alba, \& Beaty, 1993). Conceptions of learning have repeatedly attracted educational researchers to emphasize their focus on (for example Dart et al., 2000; Lin \& Tsai, 2008; Purdie \& Hattie, 2002; Rosario et al., 2014; Sadi, 2014, 2015; Tsai, 2004) because of the importance of understanding the way individual learner's experiences learning (Pillay \& Boulton-Lewis, 2000).

The study of learning conceptions is rooted in the research of educational psychology, especially 'Students Approaches to Learning' (SAL) research tradition (Benson \& Lor, 1999), which was pioneered by Säljö in 1979. According to that research, five categories of learning conceptions were identified: (1) enriching knowledge, (2) memorizing, (3) acquiring facts, procedures, (4) abstracting meaning, and (5) understanding realities. The sixth category, changing as a person, was added by Marton et al. (1993). These six categories of learning conceptions are believed to be hierarchical to indicate a developmental phase. The first three categories are classified into a surface-level approach, while the last three are at a deep level (Marton \& Säljö, 1976). The surface-level approach relates to the various elements of the learning content that the learners focus on. In contrast, the deep-level approach relates to the aims of learning.

Students 'conceptions of learning closely relate to students' social and cultural contexts (Marton \& Booth, 1997), in particular to their educational situation. For instance, Thompson (2007) mentioned the three sources of students' learning conceptions shapers: (i) personal experiences (e.g., family background, culture, geography, socioeconomic, religion, etc.), (ii) in-school experiences, and (iii) formal knowledge (gained in school). This is in line with Säljö (1979, p.106), “... learning does not exist as a general phenomenon. To learn is to act within man-made institutions and to adapt to the particular definitions of learning that are valid in the educational environment in which one finds oneself'. In other words, students of a particular educational setting tend to conceive different conceptions of learning from those of different settings. The proofs have been shown by some studies. For example, a study by Lin and Tsai (2008) revealed that university students in Taiwan hold six types of the conception of learning management: memorizing, testing, applying, gaining better status, understanding, and seeing in a new way. A later study by Sadi (2014) showed that conceptions of learning genetics conceived by Turkish university students include memorizing, testing, researching, applying, and seeing in a new way. Moreover, the study conducted by Byrne and Flood
(2004) to Irish accounting students discovered that most of the students conceive learning as knowledge acquisition and/or application. On the other hand, Peterson, Brown, and Hamilton (2013) differentiate Asian and European tertiary students' conceptions of learning as a duty. In English learning domain, Zheng, Liang, Yang and Tsai (2016) identified students' learning-English conceptions: (1) memorizing, (2) testing, (3) drilling and practicing, grammar, vocabulary, and pronunciation, (4) increasing one's knowledge, (5) application and communication, and (6) understanding and seeing in a new way. However, it can be observed that these studies are conducted on tertiary level students with only a few such as Dart et al. (2000), Peterson, Brown, and Irving (2010), and Sadi (2015) on secondary school students.

\section{Learning strategies}

Learning strategies are very important for every individual learner. Likewise, language learning strategies are needed by a language learner to make it easier, faster, more joyful, and more effective (Oxford, 2001) to achieve the set outcomes. It also enables students to become more autonomous and long-life learners (Lee and Oxford, 2008) to successfully master a second language (Brown, 2001). In short, language learning strategies are learners' deliberate or automatic actions to regulate how a language is learned (Griffiths and Cansiz, 2015).

Oxford (2001) divided language learning strategies into six major varieties, including cognitive, mnemonic, metacognitive, compensatory, affective, and social. Cognitive strategies support language learners to associate the new information to their prior knowledge, such as guessing from context, analyzing, examining, and reasoning. Mnemonic strategies help language learners to link a new item with a known thing in a simplistic way. Metacognitive strategies support language learners to know themselves better as language learners by managing the learning process. Compensatory strategies enable language learners to use English in their limited knowledge when having communication using English in the oral or written mode. Affective strategies enable language learners to identify their feelings and help them deal with anxiety through actions such as deep breathing, laughter, positive self-talk. Social strategies support language learners to learn with others. Above all, according to Chamot and O'Malley (1994), metacognitive is the executive process that enables an individual learner to manage, anticipate or plan a task, determine how successfully the plan is being executed, and evaluate the success of the learning and the plan after the activities. Thus, it can be said that metacognitive strategies are complex and high-level strategies.

\section{METHOD}

\section{Respondents}

The participants of this research were students of an Islamic Senior High School at a Pesantren in Bandung, 
West Java, Indonesia. 169 students were involved in learners' learning conceptions, and 209 students were involved in identifying learners' learning strategies. They took part in this research voluntarily. Female students were chosen due to the ease of accessibility since that Pesantren male and female students are separated in different classrooms and buildings. Besides, in the Pesantren environment, students usually interact and communicate more freely and open to people of the same gender.

\section{Instruments}

This study employed an interview and questionnaires to gain data. The questionnaire consisted of two parts. The first part contained close-ended items, while the second part contained open-ended items. The close questionnaire, which was used to identify students' conceptions of learning English, was adapted from Purdie and Hattie's (2002) COLI (Conception of Learning Inventory). The COLI consists of 32 items and 6 sub-scales: (i) learning as receiving information (5 items), (ii) learning as remembering, understanding and using information ( 9 items), (iii) learning as a duty (3 items), (iv) learning as a personal change (8 items), (v) learning as a process not bounded by time and place, and (vi) learning as the development of social competence. The close questionnaire which was used to identify students learning strategies was adopted from Oxford's (1990) SILL (Strategy Inventory of Language Learning). The questionnaires were first translated into the Indonesian language in order that the students were able to understand it easily and to avoid the participants' misunderstanding, which can reduce the accuracy of the data. Meanwhile, the open-ended items were the followup questions from the close-ended section. It was to gain data whether they had any learning conception / learning strategy other than that of mentioned in the close ended question. This part required students to respond to the Indonesian language. Finally, the interview was done to check and sharpen the gained data from the questionnaire.

\section{Procedures}

Before administering the questionnaires, the authors firstly informed respondents that the questionnaire was used to assess the students' conceptions of learning English. They were also given an explanation about the purposes of the research and how to respond to the questionnaires. In the next step, the students were asked to rate 32 items of the close-ended questionnaire using a Likert scale, ranging from 1, representing "strongly disagree," to 5, representing "strongly agree." In the second section, they were asked to answer the follow-up questions, whether they have learning conception other than those mentioned in the previous part. If they had, they were asked to answer 'yes' and write down their conception of learning (what learning means to them). In the questionnaire of students learning strategies, the students were asked to rate 50 items of the closed-ended questionnaire of SILL using a Likert scale, ranging from 1 to 5 . Score 1 represents "Never or almost never true of me" (i.e., rarely or never used), and 5 represents "Always or almost always true of me" (i.e., always or almost always used). In the second part, they were asked whether they have learning strategies other than that mentioned in SILL. Finally, after the data from the questionnaires were analyzed, six students were interviewed. The interview was recorded and transcribed to be analyzed.

\section{Data analysis}

In analyzing the close-ended questionnaires, the descriptive quantification (involving average number, frequency, and percentage) was used. The students' responses to the questionnaires were rated. The students' response to each conception item is rated using a Likert scale of 1 through 5. To make it easier to analyze the students' scores, the data are presented in a table. Then, in each group of conceptions of learning and learning strategy, the students' scores were summed, then averaged. To avoid the risk of human error that can reduce the accuracy of data computation, Microsoft Excel statistical software was employed to assist with the quantification.

On the other hand, the data from the open-ended questionnaire and interview were analyzed employing Miles and Huberman's (1994) framework of qualitative data analysis: data reduction, data display, and drawing and verifying conclusions.

\section{FINDINGS AND DISCUSSION \\ Conceptions of learning English}

The modified COLI was used to investigate the tendency of students' learning English conception. Table 1 shows the students' tendency.

Table 1. Students preference of conceptions of learning

\begin{tabular}{lrrrrrr}
\hline Group & INFO & \multicolumn{1}{c}{ RUU } & DUTY & PERS & PROC & \multicolumn{1}{c}{ SOC } \\
\hline Frequency & 31 & 10 & 103 & 28 & 53 & 59 \\
Percentage & $18.3 \%$ & $5.9 \%$ & $60.9 \%$ & $16.6 \%$ & $31.4 \%$ & $34.9 \%$ \\
Rank\# & 4 & 6 & 1 & 5 & 3 & 2 \\
\hline
\end{tabular}

The data in table 1 shows that the majority of students (103 out of 169 students, equals 60.9\%) prefer to conceive learning English as a duty (DUTY). The second highest frequency falls on the conceptions of learning as the development of social competence (SOC). It means that some students (59 out of 169 students, equals $34.9 \%$ ) prefer to view learning as the development of social competence. The third rank is occupied by the conception of learning as a process not bound by time or place (PROC). There were 53 students out of $169(31.4 \%)$ students who prefer to hold the conception of learning as a process not bound by time or 
place. The next highest occurrence of students' preference for the conception of learning is learning as gaining information (INFO). There were 31 students out of $169(18.3 \%)$ who prefer to see learning as gaining information. The fifth rank falls on the conceptions of learning as personal change (PERS). 28 students out of 169 prefer to view learning as personal change. The lowest rank is on the conceptions of learning as remembering, using, and understanding information (RUU). there were only 10 students out of 169 who prefer to choose learning as remembering, using, and understanding information (RUU)

Based on the finding, it is revealed that most students chose to learn as a duty as their conception of learning. This is in line with Li's (2012) study, which showed that "learning is not just academic for Chinese/Asian; it is more centrally a personal moral obligation and commitment." Moreover, Meyer and Kiley's (1998) research on Indonesian postgraduate students' conceptions of learning emphasized that the students are "being influenced by a sense of duty."

The data from open-ended questions showed that there were 89 students out of 169 students who answered that they had learning conceptions other than that of the mentioned in the previous part (the closeended) of the questionnaire. However, despite asking the students to state their conceptions of learning other than the ones mentioned in the previous part of the questionnaires, some of the responses could be grouped with Purdie and Hattie's (2002) conceptions of learning. For example, some students wrote:

1. Learning is adding knowledge and not only learning subjects at schoolbut also understanding how to be a virtuous pers on.

2. Learning is when we are able to derive hikmah 'wisdom or deep meaning' in every life we live.

3. Learning is finding knowledge, which is something every Muslim is obliged to do (both male and female), to avoid the stupidity and get Rida Allah 'Allah's pleasure.'

4. Through learning, we can know everything. The Arabic proverb says, "seek knowledge even to the land of China." Also, another one in the Hadith says, "seek knowledge from the cradle to the grave'. It is because searching for knowledge is borderless.

In response [1], there are three conceptions of learning that the student hold. First, she conceived learning as personal change (PERS); in particular, PERS5 'increased knowledge helps me become a better person'. It was hinted by the student's first sentence, especially in her main clause, 'Learning makes me understand how to be a good person.' Second, she believed learning as the development of social competence (SOC), especially that learning is knowing how to be considerate to others (SOC2). This is inferred from the student's expression '... who benefit my country, nation, and religion'. Third, she viewed learning as gaining information (INFO). This is based on her sentence 'learning also widens my knowledge.'

In response [2], the student said that learning enables her to derive hikmah 'wisdom or deep meaning. In Purdie and Hattie's (2002) classification of conceptions of learning, it is included in RUU (learning as remembering, using, and understanding information), particularly RUU9, 'learning is finding out what things really mean.' Her conception of learning seems affected by Islamic teaching because she used the word hikmah, which comes from the Arabic language and closely associated with Islamic teaching.

In response [3], the learner conceived learning as gaining information (RUU). It is hinted by her sentences, 'Learning is finding knowledge.' She also holds the conception of learning as an obligation (Duty) from God. This can be seen from her statement, 'finding knowledge is obliged to all Muslims (both male and female), to avoid the stupidity and get Rida Allah 'Allah's pleasure.' This conception also related to Islamic teaching because the respondent explicitly mentions Islamic words such as Muslims, rida, and Allah.

In response [4], the students conceived learning as a process that is not bounded by time and place (PROC). To strengthen her argument, she quoted: (1) a Hadith, "seek knowledge from the cradle to the grave"which means that learning is time-boundless, since the beginning of humans' life until the death comes, and (2) Arabic proverb, "seek knowledge even to the land of China" which means that knowledge is very important, and thus it must be searched even to a very far place. The students' conceptions of learning are clearly influenced by Islamic teaching since she quoted a Hadith, the prophet Muhammad's saying.

The result showed that, in general, the learners' various conceptions of learning could be included in Purdie and Hattie's (2002) categories of conceptions of learning. The data also showed that some students had multiple conceptions of learning since they had more than one conception. In addition, some of their conceptions of learning are related to their religious teaching, Islam.

The data from the open question of the questionnaire was supported by the data from the interview. The data suggests that the sense of duty colored the students' English learning conceptions. The followings are examples.

Interviewer: What does learning English mean to you?

Interviewee: Relax, happy.

Interviewer: What makes you relax and happy when learning English?

Interviewee: Because English is simpler and easier than other language.

Interviewer: Can you give an example?

Interviewee: In pondok I study Arabic and English. I mean, learning Engllish is difficult, but Arabic is more difficult. I can understand English subject easier and better than Arabic subject. It is because Arabic has more hukum-hukum

Interviewer: What do you mean by hukum-hukum? Is it hukum tajwid? 
Interviewee: No, it is hukum nahwu, in English it is grammar.

Interviewer: Do you think that learning English is a form of performing one of your religion teachings?

Interviewee: To me, learning all subjects [the school subjects] is ibadah. All are to develop ourselves.

Interviewer: Does Islam or Quran state that Muslim must learn English?

Interviewee: [In the Quran] there is no explicit statement of obligation to learn English. But to learn many things and to seek knowledge, yes there is [the obligation]. I mean, learning English is also learning, to seek knowledge. And all subjects are the same.

Other students conceived learning English is as a duty because of its benefit to serve her community. Let's see the following excerpt from the interview.
Interviewee : Learning English is useful, to help my sister, my brother or neighbor such as in doing their homeworks. To help others. Hairun naas anfauhum lin nas 'The more a person gives advantages to others, the better he/she is.'

Based on the above data, it was revealed that the finding of this research enriches Purdie and Hattie's (2002) subcategories of conceptions of learning. They are (1) searching for new knowledge which can be grouped into conception of learning as 'gaining information (INFO), and (2) children duty toward parents, (3) a duty toward community, and (4) fulfilling religion teaching which can be included into the conception of learning as a duty (DUTY). The following are the new subcategories of students' conceptions of learning and examples of students' responses.

Table 2. Students conceptions of learning

\begin{tabular}{cc}
\hline $\begin{array}{c}\text { Categories of conceptions of } \\
\text { learning }\end{array}$ & Examples of students responses \\
\hline
\end{tabular}

\section{Gaining information}

An effort to seek for knowledge Learning is our effort to seek knowledge (FA)

A duty

a. Children's duty toward parents

b. A duty toward community

c. Fulfilling religion teaching

Learning is trying hard to gain knowledge (SF)

Learning makes me become a better achiever, and it is a way to make my parents happy. Learning is one of the obligations of a child to his/her parents. (ED)

By learning, I want to make my parents proud of me when I succeed. So, my parents will not be disappointed with what they have striven for. (NA)

Learning is important because by learning, we will have wide knowledge, and we will benefit the community. (NL)

Learning makes me understand how to be a good person who benefits my land, nation, and religion. Learning also widens my knowledge. (SC)

Learning is our effort to get something that will be useful for us. Learning means sharing, sharing what we know (what we have learned) to others.(SA)

By learning, we can worship Allah well. Because if worship is without knowledge, then the worship will be not good.(SF)

Learning enlarges our insight. And Allah says [in the Quran]: "Allah raise the degree (dignity) of the people who are knowledgeable." (MS)

Learning is our effort to find knowledge, and finding knowledge is an obligation from Allah. (MI)

The first finding from the students' answer was that there is a new category of the conception of learning. Some students conceive learning as menuntut ilmu or mencari ilmu 'pursuing knowledge. This resembles Purdie and Hattie's (2002) category of learning as gaining information (INFO). The term menuntut or mencari indicates that the main point in learning is the 'effort' to gain the knowledge, regardless of the results, whether they succeed or not in their attempt to gain the knowledge. This is proved by students' statements" ... although I sometimes do not understand the lesson, I have to try, and some I can. Because God sees our effort, not the results." This finding is probably influenced by hidden factors that are not investigated in this study. One of the factors is the students' background of culture. In Indonesian culture, the word learning 'belajar' is commonly associated with the phrase menuntut ilmu or mencari ilmu 'pursuing knowledge' or 'seeking for knowledge.' In addition, the Indonesian dictionary defines the word belajar as 'learning' as 'trying to gain intelligence or knowledge. Li (2005) noted: "Because learning beliefs are not innate but develop through the process of socialization together with individual's own active construction, the belief is profoundly influenced by cultural value systems."

A few students viewed learning as a duty to their parents. This is reflected by the students' responses, such as 'to make my parents happy' and 'to make my parents proud of me.' This is in line with Salili's (1996) finding, which concluded that Asian students consider education a duty toward their parents. In addition, this 
students-conception as a duty to their parents seems to have a close relation to the students' achievement. Because, in their responses, along with their conceptions of duty to their parents, they mention achievement-related words such as 'a better achiever' and 'when I succeed.' This is in line with Peterson et al. (2013) that among Asian students, learning as duty factors that relate to achievement. Further, they noted, "learning out of moral obligation to the collective culture (e.g., family and society) and learning as something that requires hard work, positively related to academic achievement."

There were a few students who conceive learning as their duty to their community. This is indicated by the students' responses, such as, 'Learning is important because, by learning, we will have wide knowledge, and we will benefit our community.' This is in line with Merriam and Kim (2008), who noted that from a nonwestern perspective, learning is the responsibility of the members of the community because learning enables them to develop their community. The community itself can be geography-based, national-based, or spiritual/religion-based. This is inferred from the student's expression '... who benefit my land, nation, and religion'. In other words, the students hold the conception that they had an obligation to share what they have learned to their community to help and promote their community. This is proved by Kamis and Muhammad (2007) that in Islam, there is Fard Kifayah knowledge. It is meant that if there is/are a/some members of the society acquire certain knowledge and share it with the society, others are absolved of that obligation; otherwise all members of the community get $\sin$.

Many of the students' answer indicates that their learning was to fulfill their religion teaching (Islam). In students' responses, they mentioned that learning is a part of Islamic teachings. Some of them quote the sources, either The Quran verses, the prophet Muhammad's sayings (the Hadith), or ulama's advice. Regarding Purdie and Hattie's (2002) categories of conceptions of learning, this can be included in the conception of learning as a duty. However, Purdie and Hattie (2002) did not specify 'what' or 'who' require them to learn. While in this study, it was found that the students conceived learning as a mandate from Islam or Allah.
To conclude, in general, most students conceived learning English as a duty. This is classified into three: a duty toward their parents, moral duty toward their community, and a duty to fulfill their religious teaching. This is an indication that their culture and religion take part in shaping their conceptions of learning. Specifically, the data indicated that students conceived learning English are learning grammar, vocabulary, speaking, listening, and reading.

\section{Language learning strategies}

There were 209 students who voluntarily responded to the questionnaires of the English-learning strategy. The close-ended part of the questionnaire was taken from Oxford's (1990) Strategy Inventory of Language Learning (SILL) version 7.0 (Version for Speakers of Other Languages Learning English). This is made up of 50 items. The following is the data presentation of students' preference for learning strategy use. Considering the data in Table 3, the metacognitive strategy (group D) was the most frequently chosen by the students as their most favorite strategy in learning English. Based on the results, 93 students (44\%) used the metacognitive strategy (for planning, organizing, and evaluating one's language learning). The second most frequently used was the affective strategy (group E). This was used by 37 students (18\%), and it is the strategy for managing emotion and motivation. The third rank was occupied by social strategy (group F), used by $31(15 \%)$ of the 209 students. This strategy helps learners to learn and work with other people. The fourth was a compensation strategy (group C), in which 30 students (14\%) used it while learning English. It is the strategy that enables learners to use English (the new language) for both comprehension and production in their limited knowledge about English. The fifth rank was occupied by cognitive strategy, chosen by 14 students (7\%) while learning English. It gives the steps to understand, prepare, and use English. Then, the last ranked was the memory strategy. Only 9 students (4\%) used it while learning English. The strategy is used to store and retrieve English knowledge or skill. In addition, there were 5 students (2\%) who employed more than one strategy (multi-strategy usage) in learning English.

Table 3. Students' preference for learning strategy use

\begin{tabular}{lccc}
\hline LS Groups & Frequency of LS preference & Percentage & Rank \\
\hline Memory ( A ) & 9 & $4 \%$ & 6 \\
Cognitive ( B ) & 14 & $7 \%$ & 5 \\
Compensation C ) & 30 & $14 \%$ & 4 \\
Metacognitive ( D ) & $\mathbf{9 3}$ & $44 \%$ & 1 \\
Affective ( E ) & 37 & $18 \%$ & 2 \\
Social ( F ) & 31 & $15 \%$ & 3 \\
\hline
\end{tabular}

The data from the open question showed that there were 73 students out of 209 reported to have utilized other strategies, which were not mentioned in the previous part (the close-ended) of the questionnaire.
However, they were asked to their personal opinions, and all responses were grouped into Oxford's (1990) strategy of learning a language. 

obtained.

The following includes examples of responses

1. Dengan cara membuka channel youtube dan mencari native, kemudian mengikuti cara pronunciation yg benar.

'By opening the YouTube channel and searching native speakers, therefore, following the correct pronunciation.'

2. Dengan mendengarkan musik dan menonton film/video dengan subtitle inggris dan dengan aplikasi pembelajaran bahasa - bahasa asing di handphone.

'By listening to music and watching movies / videos with English subtitles and also utilize applications for learning foreign languages on mobile phones.'

In sentence [1], the student stated that the strategy employed involves opening YouTube channels and searching for native speakers, and following the correct pronunciation. Moreover, Oxford's (1990) SILL includes it to cognitive strategy, particularly hinted in item number 15 and 12: "I watch shows, or visit movies spoken in English" and "I practice the sounds of English," respectively. In response [2], learning was accomplished by listening to music/songs and watching movies. Therefore, this is included in cognitive strategy, especially those listed in item number 12 and 15.

To conclude, metacognitive strategies (Strategy D) were identified as the students' first choice for language learning, which indicates the preference to perform actions beyond purely cognitive devices. Therefore, they are the actions that provide ways of coordinating personalized knowledge acquisition, especially by (1) centering learning through paying attention to others' speak, and delaying this speech production, in order to focus on listening, (2) arranging and planning the training process, (3) self-evaluation, and (4) selfmonitoring. This specifically regards cognitive learning strategies, especially through the practice with sounds, which is most popular. Moreover, the second involved receiving and sending messages, (through peculiar resources), and practicing (especially with sound and writing systems). Furthermore, the second, third, and fourth most frequently used non-cognitive sub-strategy were categorized as affective strategy, particularly through lowering anxiety (by relaxation), and selfencouragement (by taking risk wisely).

\section{CONCLUSION}

This paper has presented the results of the study on conceptions of learning and language learning strategies used by students of an Islamic Senior High School of a pesantren in Bandung, West Java, Indonesia. The study found that in general, they tend to conceive learning English as a duty - in order to make their parents happy, to serve their community with their knowledge, and most of all, as a way to show their devotion to Allah the all mighty. In other words, they view learning as an ibadah in the Islamic concept. For them, learning English is an ibadah, that is performing one of Islamic teachings, seeking knowledge. In other words, there is no specificity or exclusivity for English. The English position is the same as other subjects. It is also found that most students prefer to use metacognitive strategies to enhance their English learning. To conclude, although the students' tendency of the conception of learning refers particularly to the surface level of learning, most of the students used relatively complex and high-level strategies when it comes to the learning process as they used metacognitive strategy.

Finally, it should be mentioned that the data of this study mostly relied on the questionnaire. This suggests that this research has its own weaknesses. It is then recommended that further research involving more instruments and more participants in a different context in Indonesia.

\section{REFERENCES}

Benson, P \& Lor, W. (1999) Conceptions of language and language learning. System, 27(4), 459-457. doi: 10.1016/s0346-251x(99)00045-7

Brown, H. Douglas. (2001). Teaching by principle and interactive approach to language pedagogy. New York: Longman Inc

Byrne, M., \& Flood, B. (2004). Exploring the conceptions of learning of accounting students. Accounting Education, 13(sup1), 25-37. doi: 10.1080/0963928042000310779

Chamot, A. U., \& O'malley, J. M. (1994). The CALLA handbook: Implementing the cognitive academic language learning approach. New York: AddisonWesley Publishing Company.

Dart, B. C., Burneet, P.C., Purdie, N., Boulton-Lewis, G., Campbell. J., \& Smith, D. (2000). Students' conception of learning, the classroom environment and approaches to learning. Journal of Educational Research, 93(4), 262-270. doi: 10.1080/00220670009598715

Entwistle, N. J., \& Peterson, E. R. (2004). Conception of learning and knowledge in higher education: Relationship with study behavior and influences of learning environment. International Journal of Educational Research, 41(6), 407-428. doi: 10. 1016/j.ijer.2005.08.009

Griffiths, C. , \& Cansiz, G. (2015). Language learning strategies: An holistic view. Studies in Second Language Learning and Teaching , 5(3), 473-493. doi: 10.14746/s sllt.2015.5.3.7

Kamis, M. \& Muhammad, M. (2007). Is lam's lifelong learning Mandate. In Merriam, S. B. (ed.), NonWestern Perspectives on learning and knowing. Krieger pub. Co.

Klatter, B. E., Lodewijks, H. G. L. C., \& Aarnoutse,C. A. J. (2001). Learning Conceptions of young students in the final year of primary education. Learning and instruction, 11(6), 485-516. doi: doi.org/10.1016/s0959-4752(01)00002-0 
Lee, K. R., \& Oxford, R. (2008). Understanding EFL learners' strategy use and strategy awareness. Asian EFL Journal, 10(1), 7-32.

Li, J. (2005). Mind or Virtue: Western and Chinese beliefs about learning. Current Directions in Psychological Science. 14(4), 190-194. 10.1111/j.0963-7214.2005.00362.x

Li, J. (2012). Culturalfoundations ofleaning: East and west. Cambridge, UK: Cambridge University Press.

Lin, H-M \& Tsai, C-C. (2008). Conceptions of learning management among undergraduate students in Taiwan. Management Learning. Los Angeles, London, New Delhi, Singapore and Washington DC : Sage Publications.

Malone, K., \& Tranter, P. J. (2003). School grounds as sites for learning: Making the most of environmental opportunities. Environmental Education Research, 9(3), 283-303.

Marton, F. \& Säljö, R. (1976). On Qualitative differences in learning: I-Outcome and Processes. British Journal of Educational, 46(2), 115-127, 1976. doi: 10.1111/j.2044-8279.1976.tb02304.x

Marton, F., Dall'Alba, G. \& Beaty, E. (1993) Conceptions of learning. International Journal of Educational Research, 19(3), 277-300.

Marton, F. \& Booth, S. (1997). Learning and awareness. Mahwah, NJ: Lawrence Elbraum.

Merriam, S.B. \& Kim, Y.S. (2008). Non-Western perspectives on learning and knowing. New Directions for Adult and Continuing Education 2008(119), 71-81. doi: 10.1002/ace.307

Meyer, J. H. F. \& Kiley, M. (1998) An exploration of Indonesian Postgraduate students' conceptions of learning. Journal of Further and Higher Education, 22(3), 287-298. doi: 10.1080/0309877980220304

Miles, M.B. \& Huberman, A.M. (1994). Qualitative Data Analysis. Thous and Oaks, CA: Sage Publication.

Oxford, R. L. (1990). Language learning strategies: what every teacher should know. New York: Newbury House Publishers.

Oxford, R. L. (1996). (Ed.) Language learning strategies around the world: Crosscultural perspectives. Honolulu, HI: University of Hawaii Press.

Oxford, R. (2001). Integrated Skills in the ESL/EFL Classroom. ERIC Digest.

Oxford, R. L., \& Ehrman, M. E. (1995). Adults' language learning strategies in an intensive foreign language program in the United States. System, 23(3), 359-386. doi: 10.1016/0346$251 \times(95) 00023-d$

Peterson, E. R., Brown, G. T. L. \& Irving, S. E. (2010). Secondary schoolstudents' conceptions of learning and their relationship to achievement. Learning and individual differences, 20(3), 167-176. doi:10.1016/j.lindif.2009.12.004.
Peterson, E. R., Brown, G. T. L. \& Hamilton, R. J. (2013) Cultural differences in tertiary student conceptions of learning as duty and students achievement. International Journal of Quantitative Research in Education, 1(2), 167. doi: 10.1504/ijq re.2013.056462

Pillay, H., \& Boulton-Lewis, G. (2000). Variations in conceptions of learning in construction technology: Implications for learning. Journal of Education and Work, 13(2), 163-181. doi: 10.1080/713676984

Purdie, N. and Hattie, J. (2002). Ass essing Students' conceptions of learning. Australian Journal of Educational \& Developmental Psychology, 2, 1732.

Rosario, P., Núñez, J. C., Azevedo, R., Cunha, J., Pereira, A.,\& Mourão, R. (2014). Understanding gypsy children's conceptions of learning: A phenomenographic study. School Psychology International,35(2), 152-166. doi: $10.1177 / 0143034312469304$

Saengboon, S. (2004). Second language acquisition (SLA) and English language teaching (ELT). PASAA, 35(1), 11-34.

Sadi, Ö. (2014). Students' conceptions of learning in genetics: A phenomenographic research. Journal of Turkish Science Education. 11(3), 53-63. doi: $10.12973 /$ tused.10118a

Sadi, Ö. (2015). The analys is of high schoolstudents' conceptions of leaning in different domains. International Journal of Environmental and Science Education, 2015, 10(6), 813-827. 10.12973/ijese.2015.278a

Salili, F. (1996). Learning and motivation: An Asian perspective. Psychology and Developing Societies, 8(1), 271-279. doi: 10.1080/0144341960160304

Säljö, R. (1979). Learning about Learning. Higher Education, 8(4). 443-451. doi: $10.1007 / \mathrm{bf0} 1680533$

Suherdi, D. (2018). SMSLEFA: An alternative synergistic multilayered analys is of students' learning engagement in EFL context. Indonesian Journal of Applied Linguistics, 8(1), 11-20. doi: 10.17509/ijal.v8i1.11457

Thompson, L. K. (2007). Considering belief in learning to teach music. Music Educators Journal.93(3), 30-35. doi: 10.1177/002743210709300317

Tsai, C.C. (2004). Conceptions of learning science among high schoolstudents in Taiwan: A phenomenographic analys is. International Journal of Science Education, 26(14), 1733-1750. doi: 10.1080/0950069042000230776.

Zheng, C., Liang, J.C., Yang, Y.F., \& Tsai, C.C. (2016). The relationship between Chinese university students' conceptions of language learning and their online self-regulation. System, 57, 66-78. doi: 10.1016/j.system.2016.01.005 